\title{
First record of the red alga Griffithsia capitata (Ceramiales, Rhodophyta) in the southwestern Caribbean Sea, Western Atlantic
}

\author{
M. Natalia Rincón-Díaz , Brigitte Gavio ${ }^{1,2^{*}}$, Michael J. Wynne ${ }^{3}$ and Adriana Santos-Martínez ${ }^{1}$
}

\begin{abstract}
The red algal species Griffithsia capitata (Ceramiales, Rhodophyta), native to the Canary Islands and Madeira, is reported for the first time from San Andres Island, International Biosphere Reserve Seaflower, Caribbean Sea. All specimens, which are small and easily overlooked, were found in coral reef habitats, at depths in the range of 9-17 m, growing mostly on coral rubble or as epiphytes on larger algae. The species was found with all reproductive stages. Its morphological and reproductive features are described and discussed. Whether this new finding is a recent introduction or a species with a natural amphiatlantic distribution still needs to be addressed.
\end{abstract}

Keywords: Atlantic Ocean, Colombia, Griffithsia capitata, Marine algae

\section{Introduction}

The Caribbean marine flora has received considerable attention (Miloslavich et al. 2010), and it is rather well known (Costello et al. 2010), if compared to other biogeographic regions. It is species-rich, and the flora is rather homogeneoeus across the whole basin. As in many other regions, in the Caribbean the marine flora is dominated by red algae, and most species are small and epiphytic. Due to the progressive degradation of coral reefs in the region, macroalgae have proliferated, especially turf algae, and now cover what several decades ago was coral reef.

San Andres Island is part of the International Biosphere Reserve Seaflower, one of the largest marine reserves in the world (CORALINA-INVEMAR 2012). The marine flora of the island is not thoroughly known because historically it has received little attention (Albis-Salas and Gavio 2011). In the past few years, macroalgal sampling has been undertaken in the whole

\footnotetext{
*Correspondence: bgavio@unal.edu.co

'Universidad Nacional de Colombia, Sede Caribe. San Luis Free Town \#

52-44, San Andrés Isla, Colombia

'Departamento de Biología, Universidad Nacional de Colombia, sede Bogotá,

Ciudad Universitaria, Bogotá, Colombia

Full list of author information is available at the end of the article
}

archipelago, revealing a flora much more diverse than previously appreciated (Albis-Salas and Gavio 2011; Ortiz and Gavio 2012; Reyes-Gómez et al. 2013; Gavio et al. 2013; 2015). Most of the algal diversity is composed of small and easily overlooked species, although most of these taxa are often relatively abundant and widespread in the Caribbean basin. One of the species recently found is Griffithsia capitata (Ceramiales, Rhodophyta), native to the Canary Islands and Madeira. Here we describe the vegetative and reproductive morphology of the plants observed, and discuss the findings as a possible recent introduction or a case of amphiatlantic distribution as a remnant of a Tethyan distribution. This is the first report of the species for the Western Atlantic.

\section{Materials and methods}

San Andres $\left(12^{\circ} 28^{\prime} 55^{\prime \prime} \mathrm{N} 81^{\circ} 40^{\prime} 49^{\prime \prime} \mathrm{W}\right)$ is an oceanic island of coralline origin situated in the southwestern Caribbean, Colombia (Fig. 1). The island is surrounded by a calcareous platform with a windward barrier reef, a lagoon with patch reefs, including leeward and windward fore reef terraces with coral carpets (Díaz et al. 1995). The leeward, western margin is composed of two submerged terraces, parallel to the coast and slightly inclined, separated by a sandy trough: one terrace is 


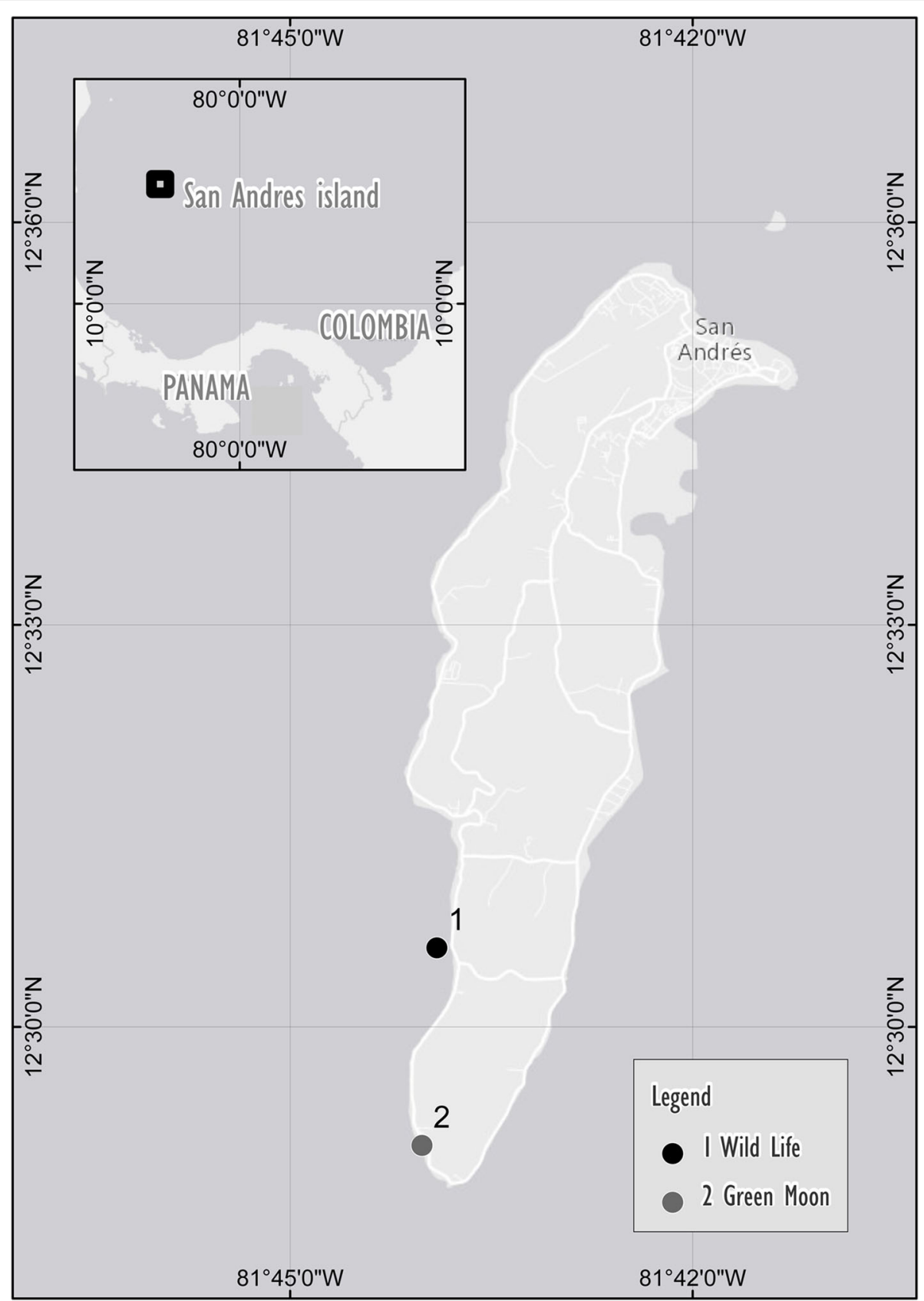

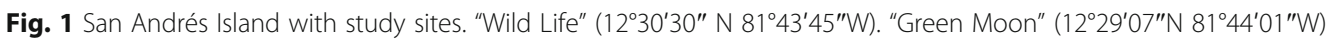

shallow (4-10 m depth) along the shore; the second is deeper (10-20 $\mathrm{m}$ depth), its outer edge dropping to the top of the insular slope below (Chaves-Fonnegra et al. 2007). All the specimens were collected on the western side of the island, at the localities "Wild Life" $\left(12^{\circ} 30^{\prime} 30^{\prime}\right.$ " $\left.\mathrm{N} 81^{\circ} 43^{\prime} 45^{\prime \prime} \mathrm{W}\right)$ and "Green Moon" $\left(12^{\circ} 29^{\prime} 07^{\prime \prime} \mathrm{N} 81^{\circ} 44^{\prime}\right.$ $01 " \mathrm{~W})$. This sector is characterized by a reef terrace with coral mat formations starting at $10 \mathrm{~m}$ depth, characterized by high species diversity of corals, sponges, octocorals and algae (Díaz et al. 2000).
The algae were collected during a macroalgal survey of the sites by scuba diving, in the wet season (from November 2012 to January 2013 and June 2013 to August 2013), and dry season (from February 2013 to May 2013) at 9-17 m depth. Specimens were preserved in $4 \%$ formalin/seawater solution. In the laboratory, algae were identified using an OLYMPUS BX51 microscope. Slide material was mounted in $50 \%$ glycerin, after staining in aniline-blue solution. Specimens were deposited in COL, the Herbarium of the Universidad Nacional de Colombia. 


\section{Results and discussion}

SYSTEMATICS

Family WRANGELIACEAE

Genus Griffithsia C. Agardh nom. cons.

Griffithsia capitata Børgesen

(Figure 2)

\section{Distribution}

This species, which has as type locality Gran Canaria, Canary Islands (Børgesen 1930), has a limited distribution in the north-eastern Atlantic Ocean. To date, it has been reported only from the Canary Islands (Gil-Rodriguez and Afonso-Carrillo 1980; Afonso-Carrillo and Sansón 1999) and the Madeira Archipelago (Levring 1974; Neto et al. 2001).

\section{Description}

Thallus delicate, pale rose, small, to $7 \mathrm{~mm}$ in height, epiphytic, erect (Fig. 2a), attached to the substrate by a basal disc (Fig. 2b); branching irregular. Cells cylindrical, $75-130 \mu \mathrm{m}$ in diameter on vegetative branches (Fig. 2c) and up to $320 \mu \mathrm{m}$ on branches with reproductive structures, 600-1000 $\mu \mathrm{m}$ long; apical cells dome-shaped in vegetative branches $75-90 \mu \mathrm{m}$ diameter, $100 \mu \mathrm{m}$ long (Fig. 2c), rounded when reproductive structures are present, $160 \mu \mathrm{m}$ diameter, (Fig. 2d). Sterile filaments are not present.
Tetrasporangia globose, 55-70 $\mu \mathrm{m}$ diameter, $55-60 \mu \mathrm{m}$ long, with basal cell $12.2 \mu \mathrm{m}$ diameter, $15 \mu \mathrm{m}$ long, in whorls encircling distal ends of subapical to median cells (Fig. 2e), with the upper cell of the vegetative filament bearing tetrasporangia. The ultimate cell of the fertile filament is often caducous. Involucral cells and trichoblasts absent.

Spermatangia develop on the ultimate cell of the fertile branch, as naked fascicles, which cover $25-30 \%$ of the apical cell as cap-like masses (Fig. 2f). The fascicles are $500 \mu \mathrm{m} \times 350 \mu \mathrm{m}$, whereas the spermatangia are $5 \mu \mathrm{m}$ long and $2.5 \mu \mathrm{m}$ diameter.

Carposporophyte terminal to subterminal, surrounded by large kidney-shaped involucral cells (Fig. 2g).

\section{Habitat and phenology}

Tetrasporangiate, male, female, and vegetative plants of Griffithsia capitata were collected from the "Wild Life" site on 2 November 2012 at 12.5 m depth (NRD037, NRD042, NRD051, NRD104 and NRD123). On 22 January 2013 at $16.8 \mathrm{~m}$ depth (NRD410 and NRD499). On 4 April 2013 at $13 \mathrm{~m}$ depth (NRD992, NRD0030, NRD0070, NRD0074 and NRD0105). On 7 June 2013 at $14 \mathrm{~m}$ (NRD0209, NRD0271, NRD0273, NRD0319, and NRD0341). On 9 August 2013 at $14 \mathrm{~m}$ depth (NRD0406, NRD0465, NRD0487 and NRD0519). Vegetative plants from the "Green Moon" site were collected on 7 December 2012 at $10.2 \mathrm{~m}$ depth (NRD148 and

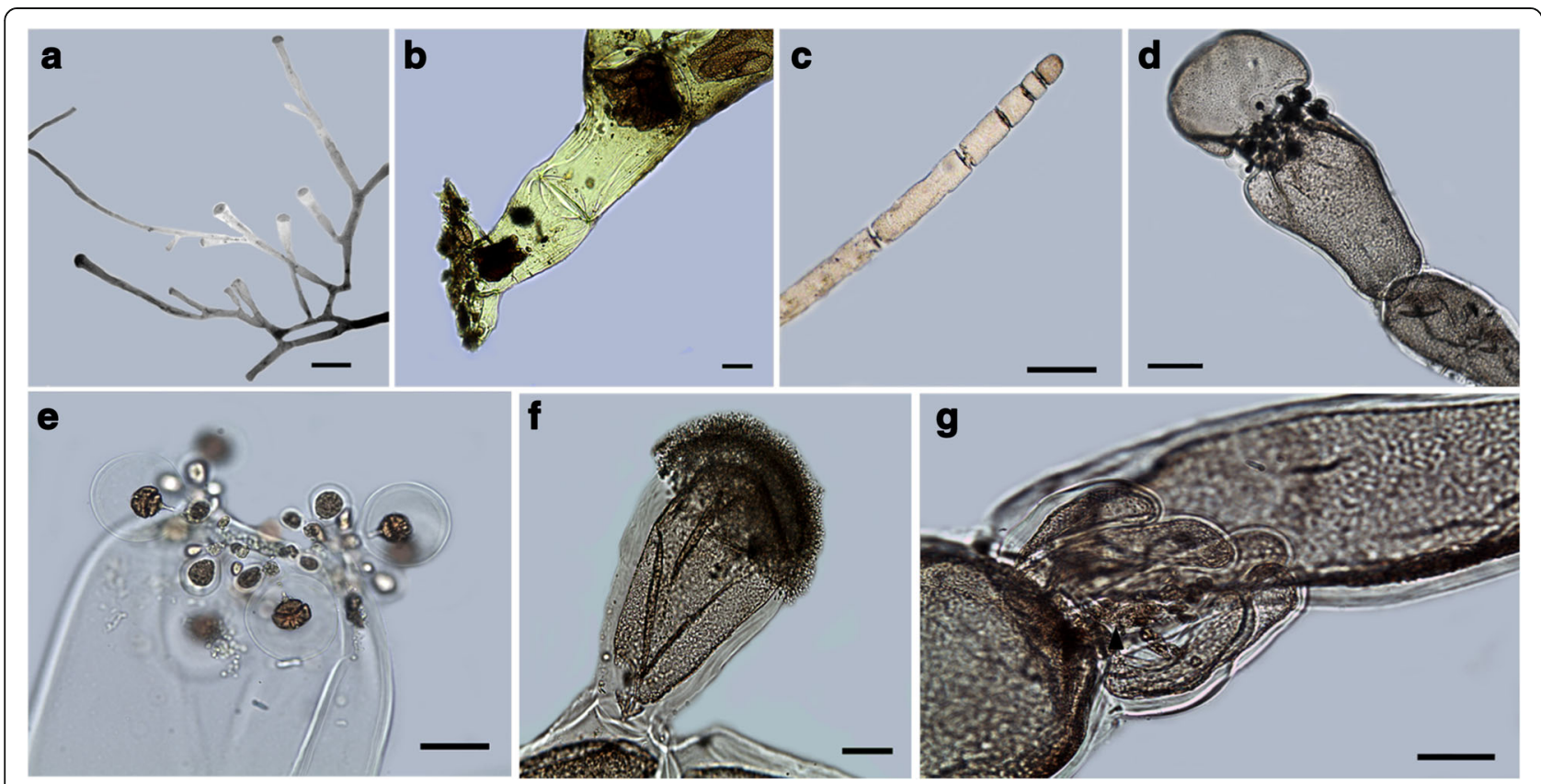

Fig. 2 Griffithsia capitata. a Habit of male gametophyte. b Basal disc. c Dome-shaped apical cell terminating vegetative branch. d Globose tetrasporangia in whorls encircling distal ends of subapical to median cells. e Tetrasporangia with loss of upper part. f Spermatangial cap developing on ultimate cell of a fertile branch. $\mathbf{g}$ Persistent kidney-shaped involucral cells which surrounded the carposporophyte (which has shed). Scale bars: a, 1 mm; b, $200 \mu \mathrm{m} ; \mathbf{c}, 250 \mu \mathrm{m} ; \mathbf{d}, 100 \mu \mathrm{m} ; \mathbf{e}, 50 \mu \mathrm{m} ; \mathbf{f}, 250 \mu \mathrm{m} ; \mathbf{g}, 50 \mu \mathrm{m}$ 
NRD326). The plants were growing on coral rubble and on larger algae, especially species of Halimeda.

\section{Remarks}

To date, eight species of Griffithsia have been reported from the western North Atlantic: G. aestivana C.W. Schneider \& C.E. Lane, G. caribaea Feldmann-Mazoyer, G. globulifera Harvey ex Kützing, G. heteromorpha Kützing, G. opuntioides J. Agardh, G. radicans Kützing, G. schousboei Mont. in Webb and G. secundiramea Vickers (Wynne 2011). Of these, only G. aestivana and G. radicans lack involucral cells around the tetrasporangia (Schneider and Lane 2007). However, G. aestivana is much larger in size, and the tetrasporangia are associated with trichoblasts, a feature not observed in G. capitata (Børgesen 1930).

Our male plants bearing terminal caps of spermatangia clearly align our species with the Griffithsia capitata group as proposed by Børgesen (1942). Only four species have been assigned to this group (Baldock 1976): G. capitata Børgesen (1930), G. weber-van-bosseae Børgesen (1942), G. globulifera, and G. rhizophora Weber-van Bosse (Børgesen 1942). Griffithsia globulifera can be separated from our specimens on the basis of its large thallus size, the large size of individual cells (to $1.5 \mathrm{~mm}$ diam), the presence of sterile filaments and also of involucral cells protecting the tetrasporangia (Taylor 1962; Littler and Littler 2000). We did not observe any trichoblasts or sterile filaments in our specimens (Fig. 2a).

Griffithsia rhizophora can be distinguished from our species because of its dichotomous branching habit, its extensive prostrate habit, and its frequent production of attachment rhizoids (Thivy and Iyengar 1963). Our specimens are totally erect and are attached to the substrate by means of a basal disc (Fig. 2b). Moreover, in G. rhizophora the cell length: width ratio is equal to 3 (Taylor 1960), while in our specimens the length: width ratio is $>3$. Griffithsia weber-van-bosseae differs from our specimen for its decumbent axis, with frequent rhizoids, and for the presence of numerous dwarf shoots forming at the upper ends of cells (Børgesen 1942). In general, our specimens fit well the description of Griffithsia capitata Børgesen. However, our thalli are smaller; our specimens were less than $1 \mathrm{~cm}$ in length, whereas Børgesen (1930) described the thalli as $2-3 \mathrm{~cm}$ high. Levring (1974) observed his specimens of this species from Madeira to be about $1 \mathrm{~cm}$ high and to carry tetrasporangia. Our specimens were fertile, and we collected the three stages of the reproductive cycle: male and female gametophytes, and tetrasporophytes. Therefore, we are confident that the observed thalli are adults and not just undeveloped juveniles.

This is the first record of Griffithsia capitata in the western Atlantic and outside its known range of distribution, which includes only the Canary Islands and Madeira in the eastern North Atlantic (Guiry and Guiry
2016). The present record expands the geographical range of the species to the Caribbean Sea, and adds to the record of species with amphiatlantic distribution. The alga is small and may have gone undetected, despite the attention that the Caribbean flora has received in the past decades. The Canary Islands, with Madeira, the Azores and the Cabo Verde islands, form the Macaronesian biogeographic region, and its marine flora has several representatives from the Caribbean basin (Prud'homme van Reine and van den Hoek 1990; Haroun et al. 1993). According to Prud'homme van Reine (1998), tropical-to-warm temperate species have a predominantly amphi-atlantic distribution. Therefore, it is possible that this species has been a natural resident of the Caribbean basin but has gone undetected due to its small size and turf habit. Longdistance dispersal might be possible due to the Canary current and the North Equatorial currents, which drift in an east to west direction (Mason et al. 2011). Pakker et al. (1996) demonstrated a lack of ecotypic differentiation between isolates from different localities on eastern and western Atlantic coasts, suggesting long-range dispersal events. Due to the presence of reproductive structures, we consider the species as well-established in the Caribbean basin; the alga is at present part of the macroalgal turf of the study sites, mainly epiphytic on Halimeda spp.

An alternative scenario includes a recent introduction of the species to the western Atlantic. Reports of small epiphytic red algae outside their range of introduction are common, and some species, within a few years after their first detection, become dominants at the demise of native turf algae (e.g. Kapraun and Searles 1990; Rindi et al. 1999; Nikolić et al. 2010).

A probable vector of introduction to San Andres island, due to the absence of aquaculture, is either ballast water or hull fouling. Various studies indicate that ballast water and sediments are one of the most important vectors of transoceanic and interoceanic movement of marine and coastal shallow water organisms (Shine et al. 2000). If this scenario results to be true, evidence of nutrient enrichment of the coastal waters of the island (Gavio et al. 2010) may favor the proliferation of turf algae (Vermeij et al. 2010), and indirectly promote the spread of Griffithsia capitata.

The origin of the species in the Caribbean basin, whether native of introduced, is not yet clear and should be addressed in the future to have a better understanding of the dynamics driving species diversity in the region.

\section{Acknowledgements}

The authors are grateful to Manuel Angarita (Landivers) and Francisco Javier Ramos for help in the field. We thank Julieta and Alejandro Rincón for assistance in managing Adobe Photoshop. Sven Zea and Paola Rodriguez provided insightful comments for field work. David Forero Parra elaborated the map of study sites, for which we acknowledge. 
This research was funded by the Universidad Nacional de Colombia, sede Caribe, through the project Hermes \# 12388. This work is contribution No. 422 of CECIMAR, Universidad Nacional de Colombia and Programa de Postgrado en Biología - Línea Biología Marina.

\section{Authors' contribution}

MNRD carried out field work, species identification and picture editing. BG carried out species identification and drafted the manuscript. MJW confirmed species identification, provided insights in the research and meliorate the manuscript. ASM provided financial and technical support for field work and laboratory analysis, and revised the manuscript. All authors read and approved the final manuscript.

\section{Competing interests}

The authors declare they do not have competing interests.

\section{Author details}

'Universidad Nacional de Colombia, Sede Caribe. San Luis Free Town \# 52-44, San Andrés Isla, Colombia. Departamento de Biología, Universidad Nacional de Colombia, sede Bogotá, Ciudad Universitaria, Bogotá, Colombia. 3 University of Michigan Herbarium, Ann Arbor, MI 48108, USA.

Received: 15 June 2016 Accepted: 15 June 2016

\section{Published online: 06 October 2016}

\section{References}

Afonso-Carrillo J, Sansón M. Algas, hongos y fanerógamas marinas de las Islas Canarias. Clave analítica. 1999. Materiales Didácticos Universitarios. Universidad de La Laguna.

Albis-Salas M, Gavio B. Notes on marine algae in the International Biosphere Reserve Seaflower, Caribbean Colombian I: new records of macroalgal epiphytes on the seagrass Thalassia testudinum. Botanica Marina. 2011;54: 537-43.

Baldock RN. The Griffithsieae group of the Ceramiaceae (Rhodophyta) and its southern Australian representatives. Australian Journal of Botany. 1976;24 509-93.

Børgesen F. The marine algae from the Canary Islands especially from Tenerife and Gran Canaria. III. Rhodophyceae. Part III. Ceramiales. Kongelige Danske Videnskabernes Selskab, Biologiske Meddelelser. 1930;9(1):1-159.

Børgesen F. Griffithsia weber-van bosseae nov. spece. Dr. A. Weber-van Bosse Jubilee Volume. Blumea. 1942;Suppl. 2:15-20.

Chaves-Fonnegra A, Zea S, Gómez ML. Abundance of the excavating sponge Cliona delitrix in relation to sewage discharge at San Andrés Island, SW Caribbean, Colombia. Boletin de Investigaciones Marinas y Costeras. 2007;36: 63-78.

CORALINA-INVEMAR. In: Gómez- López DI, Segura-Quintero C, Sierra-Correa PC, Garay-Tinoco J, editors. Atlas de la Reserva de Biósfera Seaflower. Archipiélago de San Andrés, Providencia y Santa Catalina. Instituto de Investigaciones Marinas y Costeras "José Benito Vives De Andréis" -INVEMARy Corporación para el Desarrollo Sostenible del Archipiélago de San Andrés, Providencia y Santa Catalina -CORALINA-. Santa Marta: Serie de Publicaciones Especiales de INVEMAR \# 28; 2012. p. 180.

Costello MJ, Coll M, Danovaro R, Halpin P, Ojaveer H, Miloslavich P. A Census of Marine Biodiversity Knowledge, Resources, and Future Challenges. PLoS One. 2010;5(8):e12110

Díaz JM, Garzón-Ferreira J, Zea S. Los arrecifes coralinos de la isla de San Andrés, Colombia: Estado actual y perspectivas para su conservación. Academia Colombiana de Ciencias Exactas, Físicas y Naturales Colección Jorge Álvarez Lleras N 7. Editora Guadalupe LTDA. Colombia. 1995. p. 150.

Díaz JM, Barrios LM, Cendales MH, Garzón J, Vargas-Angel B, Ferreira J, Geister J, Lopez-Victoria M, Ospina GH, Parra-Velandia F, Pinzo J, Zapata FA, Zea S. Áreas coralinas de Colombia. Serie Publicaciones Especiales No. 5. Santa Marta: INVEMAR; 2000

Gavio B, Palmer-Cantillo S, Mancera JE. Historical analysis (2000-2005) of the coastal water quality in San Andrés Island, SeaFlower Biosphere Reserve, Caribbean Colombia. Mar Pollut Bull. 2010;60:1018-30.

Gavio B, Reyes-Gómez V, Wynne MJ. Crouania pumila sp. nov. (Callithamniaceae: Rhodophyta), a new species of marine red algae from the Seaflower International Biosphere Reserve, Caribbean Colombia. Revista Biologia Tropical. 2013;61:1015-23.
Gavio B, Cifuentes-Ossa MA, Wynne MJ. Notes on the marine algae of the International Biosphere Reserve Seaflower, Caribbean Colombia V: first preliminary study on the phycological flora of Quitasueño bank. Boletín de Investigaciones Marinas y Costeras. 2015:44:117-26.

Gil-Rodriguez MC, Afonso-Carrillo J. atalogo de las algas marinas bentonicas (Cyanophyta, Chlorophyta, Phaeophyta y Rhodophyta) para el Archipielago Canario. Santa Cruz de Tenerife: Act, Aula de Cultura de Tenerife; 1980.

Guiry MD, Guiry GM. AlgaeBase. Galway: World-wide electronic publication, National University of Ireland; 2016. http://www.algaebase.org; searched on 12 April 2016.

Haroun RJ, Prud'homme van Reine WF, Müller DG, Serrao E, Herrera R. Deepwater macroalgae from the Canary Islands: new records and biogeographical relationships. Hegoländer Meeresuntersuchungen. 1993:47:125-43.

Kapraun DF, Searles RB. Planktonic bloom of an introduced species of Polysiphonia (Ceramiales, Rhodophyta) along the coast of North Carolina, USA. Hydrobiologia. 1990;204(205):269-74.

Levring T. The marine algae of the Archipelago of Madeira. Boletim do Museu Municipal do Funchal. 1974;28:5-111.

Littler DS, Littler MM. Caribbean reef plants. Washington: OffShore Graphics, Inc.; 2000.

Mason E, Colas F, Molemaker J, Shchepetkin AF, Troupin C, McWilliams JC, Sangrà P. Seasonal variability of the Canary Current: A numerical study. J Geophys Res. 2011;116:C06001. dx.doi.org/10.1029/2010JC006665

Miloslavich P, Díaz JM, Klein E, Alvarado JJ, Díaz C, Gobin J, Escobar-Briones E, Cruz-Motta JJ, Weil E, Cortés J, Bastidas AC, Robertson R, Zapata F, Martín A, Castillo J, Kazandjian A, Ortiz M. Marine Biodiversity in the Caribbean: Regional Estimates and Distribution Patterns. PLoS One. 2010;5(8):e11916.

Neto Al, Cravo DC, Haroun RT. Checklist of the benthic marine plants of the Madeira Archipelago. Botanica Marina. 2001;44:391-414.

Nikolić V, Žuljević A, Antolić B, Despalatović M, Cvitković I. Distribution of invasive red alga Womersleyella setacea (Hollenberg) R.E. Norris (Rhodophyta, Ceramiales) in the Adriatic Sea. 2010. Acta Adriatica. 2010;51(2):195-202.

Ortiz JF, Gavio B. Notes on the marine algae of the International Biosphere Reserve Seaflower, Caribbean Colombia II: diversity of drift algae in San Andres island, Caribbean Colombia. Caribbean Journal of Science. 2012;46: 313-21.

Pakker H, Breeman AM, Prud'homme Van Reine WF, Van Oppen MJH, Van Den Hoek C. Temperature responses of tropical to warm-temperate Atlantic seaweeds. I. Absence of ecotypic differentiation in amphi-Atlantic tropicalCanary Islands species. European Journal of Phycology. 1996;31:123-32.

Prud'homme Van Reine WF. Seaweeds and biogeography in the Macaronesian region. Bol Mus Mun Funchal. 1998;Suppl. no. 5:307-31.

Prud'homme van Reine WF, van den Hoek C. Biogeography of Macaronesian seaweeds. Courier Forsch-Inst Senckenberg. 1990;129:55-73.

Reyes-Gómez V, Gavio B, Velasquez H. Notes on the marine algae of the International Biosphere Reserve Seaflower, III. New records of Cyanophyta for the Caribbean coast of Colombia. Nova Hedwigia. 2013;97:349-60.

Rindi F, Guiry MD, Cinelli F. Morphology and reproduction of the adventive Mediterranean rhodophyte Polysiphonia setacea. Proceeings of the International Seaweed Symposium. 1999;16:91-100.

Schneider CW, Lane CE. Notes on the marine algae of the Bermudas. 8. Further additions to the flora, including Griffithsia aestivana sp. nov. (Ceramiaceae, Rhodophyta) and an update on the alien Cystoseira compressa (Sargassaceae, Heterokontophyta). Botanica Marina. 2007:50:128-40.

Shine C, Williams N, Gündling L. A Guide to Designing Legal and Institutional Frameworks on Alien Invasive Species, Environmental Policy and Law Paper No. 40 IUCN - Environmental Law Centre A Contribution to the Global Invasive Species Programme IUCN - The World Conservation Union. 2000

Taylor WR. Marine algae of the eastern tropical and subtropical coasts of the Americas. Ann Arbor: The University of Michigan Press; 1960.

Taylor WR. Marine algae of the northeastern coast of North America. Revised edition Second printingth ed. Ann Arbor: The Unviersity of Michigan Press; 1962.

Thivy F, lyengar ERR. A new record of Griffithsia rhizophora (Grunow) ex Webervan Bosse for India. Botanica Marina. 1963:5:33-7.

Vermeij MJA, van Moorselaar I, Engelhard S, Hörnlein C, Vonk SM, Visser PM. The effects of nutrient enrichment and herbivore abundance on the ability of turf algae to overgrow coral in the Caribbean. PLoS One. 2010;5(12):e14312.

Wynne MJ. A checklist of benthic marine algae of the tropical and subtropical western Atlantic: third revision. Nova Hedwigia Beiheft. 2011;140:1-166. 